\title{
Correction to: Thanks, We're good: why moral realism is not morally objectionable
}

\section{David Enoch ${ }^{1}$}

Published online: 12 September 2020

(c) Springer Nature B.V. 2020

\section{Correction to: Philos Stud https://doi.org/10.1007/s11098-020-01507-x}

In the original publication of the article, some of the references were published incorrectly. The corrected references are provided below.

\section{References}

Enoch, D. (2014). A defense of moral deference. Journal of Philosophy, 111, 229-258.

Enoch, D. (2018). Review of David Sobel's From Valuing to Value: A Defense of Subjectivism. Ethics, $128,672-677$.

Enoch, D. (2019). How Principles Ground. Oxford Studies in Metaethics, 14, 1-22.

Enoch, D., \& Weinshtock-Saadon, I. (forthcoming). "Oh, All the Wrongs I Could Have Performed! Or: Why Care about Morality, Robustly Realistically Understood'. Forthcoming in David Copp and Paul Bloomfield (Eds.), Oxford Handbook of Moral Realism.

Publisher's Note Springer Nature remains neutral with regard to jurisdictional claims in published maps and institutional affiliations.

The original article can be found online at https://doi.org/10.1007/s11098-020-01507-x.

David Enoch

David.Enoch@mail.huji.ac.il

1 The Philosophy Department, The Hebrew University, Jerusalem, Israel 